NBER WORKING PAPER SERIES

\title{
THE EFFECTS OF VARIABLE CAPITAL UTILIZATION ON THE MEASUREMENT AND PROPERTIES OF SECTORAL PRODUCTIVITY: SOME INTERNATIONAL EVIDENCE
}

\author{
Marianne Baxter \\ Dorsey D. Farr \\ Working Paper 8475 \\ http://www.nber.org/papers/w8475 \\ NATIONAL BUREAU OF ECONOMIC RESEARCH \\ 1050 Massachusetts Avenue \\ Cambridge, MA 02138 \\ September 2001
}

The views expressed herein are those of the authors and not necessarily those of the National Bureau of Economic Research.

(C) 2001 by Marianne Baxter and Dorsey D. Farr. All rights reserved. Short sections of text, not to exceed two paragraphs, may be quoted without explicit permission provided that full credit, including $\odot$ notice, is given to the source. 
The Effects of Variable Capital Utilization on the Measurement and Properties of Sectoral Productivity: Some International Evidence

Marianne Baxter and Dorsey D. Farr

NBER Working Paper No. 8475

September 2001

JEL No. E3, F4, O3

\section{$\underline{\text { ABSTRACT }}$}

This paper explores how accounting for variations in factor utilization rates alters the empirical characteristics of productivity residuals in the United States and Canada. Using data on 19 manufacturing industries, we study the behavior of productivity using three proxies for capital services. We find that adjusting for cyclical movements in capital utilization alters many of the empirical characteristics of productivity, both within and across countries.

Marianne Baxter

Department of Economics

Boston University

270 Bay State Road

Boston, MA 02215

and NBER

mbaxter@bu.edu
Dorsey D. Farr

Balentine \& Company

3455 Peachtree Rd., NE

Atlanta, GA 30326 


\section{Introduction}

The measurement of productivity has long been an important element of many areas of both closed and open economy macroeconomics. ${ }^{1}$ From the time of Solow's [1957] contribution, it has been common practice to measure productivity using the "Solow residual" - value added minus the contributions of capital and labor, where these contributions are measured as the quantities of capital and labor multiplied by their shares in value added.

However, the measurement of productivity has recently received a great deal of attention from empirical macroeconomists. ${ }^{2}$ This growing research agenda is largely driven by the fact that the measurement of factor utilization, an important element in cyclical fluctuations, is now thought to be crucial for the measurement of productivity. Accurate measurement of the utilization of capital is hypothesized to be particularly important. One of the main results emerging from this literature is that the Solow residual is, at best, a measure of productivity which is contaminated by measurement error. More specifically, researchers have found that the properties of the Solow residual (also called the "productivity residual") are sensitive to modifications that employ various proxies for factor utilization. When these corrections are undertaken, the resulting measure of productivity is much less volatile than the standard Solow residual; it is also much less highly correlated with output growth and is more likely to pass exogeneity tests. To date, this literature has focused on data from the United States.

The goal this paper is to explore how various utilization corrections alter our views about the nature of the productivity residuals both within and across countries, and the ways in which shocks to productivity are transmitted across countries. Using data for the U.S. and Canada, we investigate the behavior of productivity using three proxies for capital services: the capital stock; energy inputs; and materials inputs. We document, for each country separately, how the various utilization corrections alter the characteristics of the productivity residual concerning volatility, the correlation with output and labor input, and persistence. Next, we explore how correcting for

\footnotetext{
${ }^{1}$ See, for example, the contributions of Balassa [1964], Jorgenson [1995], Prescott [1986], Samuelson [1964], Solow [1957], Tinbergen [1942], and a host of others.

${ }^{2}$ See, for examples, Basu [1996], Basu and Kimball [1997], Basu and Fernald [1995], Burnside, Eichenbaum and Rebelo [1995], Costello [1993], Evans [1992], Hall [1988], Jorgenson [1995], Jorgenson and Grilliches [1967], and Shapiro [1993, 1996].
} 
variable utilization alters the predictions for sectoral interactions within and across countries. We find that adjusting for cyclical movements in capital utilization alters many of the empirical characteristics of productivity, both within and across countries.

The remainder of the paper is organized as follows. Section 2 describes the dataset and our approach to measuring the productivity residual. Section 3 presents withincountry results for these adjusted measures of productivity, focusing on volatility, the correlations with output and labor input, and the transmission of productivity across industries and countries. We compare the results for the US and Canada, and discuss how each of these statistics is affected by the utilization corrections. Section 4 studies the cross-country, cross-industry behavior of productivity. We investigate how altering the measure of capital utilization changes our view of the correlation of productivity innovations across industries, within and across countries. We also explore how alternative measures of productivity affect estimates of the parameters of the stochastic process for productivity across countries. Section 5 concludes.

\section{Empirical method and data}

This section summarizes our data and our approach to measuring sectoral productivity.

\subsection{Methodology}

Several researchers have focused on variations in capital utilization as the primary margin for adjustment of factor utilization over the business cycle. Since capital utilization cannot be directly observed, it is necessary to find a reasonable proxy for this variable. Basu [1996] argues that materials inputs are a good proxy for utilization of labor and capital. He presents a graph (his Figure 1) which plots gross output together with labor input, materials inputs, and a labor-capital aggregate. This figure shows that materials and gross output are much more highly correlated than output and labor, and even more than output and the cost-share weighted aggregate of labor and capital. Materials are likely a good proxy for capital utilization due to the simple fact that there is no intensity margin associated with adjusting materials inputs. As a result, there are no unmeasured service flows from materials inputs. If the elasticity of substitution between materials and capital is low, then materials can 
be a good proxy for the flow of services from capital.

Another popular proxy for capital utilization is energy input. The idea here is that running machines longer and keeping factories and stores open longer involves increased use of energy inputs such as electricity to keep the lights on and the machines running, and coal and gas for heating and air conditioning. Energy has been used as a proxy for capital utilization by Costello [1993] and, more recently, by Burnside, Eichenbaum, and Rebelo [1995]. ${ }^{3}$

\subsection{Data}

The data used in this paper consists of inputs and outputs for 19 manufacturing industries from the United States and Canada. Our dataset contains annual data spanning the period 1961-1991. We focus on the following industries: Food, Tobacco, Textiles, Apparel, Lumber, Furniture \& Fixtures, Paper Products, Printing \& Publishing, Chemicals, Petroleum \& Coal, Rubber \& Plastics, Leather, Stone-Clay \& Glass, Primary Metals, Fabricated Metals, Industrial Machinery, Electrical Machinery, Transportation Equipment, and Miscellaneous manufacturing. The data for the U.S. are from the NBER Productivity Database and Citibase, while the Canadian data are drawn from the Canadian Input-Output Tables and the KLEMS database. ${ }^{4}$

Output is measured using value added. Labor input is measured as total hours worked by production workers, and capital is the real stock of capital at a point in time during the year. The prior literature has suggested that appropriate measurement of capital services is critical to the measurement of the productivity residual. The capital stock is the measure most commonly used, but this measure does not allow for variations in the capital utilization rate. We explore two popular proxies for capital services: materials inputs and energy usage. ${ }^{5}$ Materials and energy are measured by the real value of spending on each, with materials containing both energy and non-energy materials expenditures. For the purpose of constructing factor shares, we used sectoral measures of total labor compensation. ${ }^{6}$

\footnotetext{
${ }^{3}$ Shapiro $[1993,1996]$ has provided substantial evidence that the workweek of capital is a good measure of capital services. Unfortunately, there is no data available for Canada on the workweek of capital.

${ }^{4}$ We thank Steve Lange for providing the Canadian data. For more information on the data, see the appendix.

${ }^{5}$ Because we lack comparable data on the workweek of capital for Canada, we unfortunately cannot explore this third popular proxy for capital services.

${ }^{6}$ We note that energy is a very small component of materials purchases and is highly correlated
} 


\subsection{Construction of productivity residuals}

This section outlines our approach to measuring productivity based on a common economic theory of production. Following Solow [1957] and others, we begin with a production function, $G($.$) , which expresses gross output \left(Y_{i t}\right)$ as a function of labor input $\left(N_{i t}\right)$, capital services $\left(S_{i t}\right)$,materials inputs $\left(M_{i t}\right)$, and the level of productivity $\left(A_{i t}\right)$ :

$$
Y_{i t}=G_{i}\left(A_{i t}, N_{i t}, S_{i t}, M_{i t}\right) .
$$

We assume that the technology governing the production of gross output combines materials inputs and value added $\left(V A_{i t}\right)$ :

$$
Y_{i t}=G_{i}\left(V A_{i t}, M_{i t}\right)
$$

where value added generated by industry $i$ in period $t$ is a constant-returns-to scale function, which is at least locally Cobb-Douglas:

$$
V A_{i t}=A_{i t} N_{i t}^{\alpha_{i t}^{N}} S_{i t}^{\alpha_{i t}^{K}}
$$

Taking logs of (3) yields the solution for the productivity residual:

$$
a_{i t}=v a_{i t}-\alpha_{i t}^{N} n_{i t}-\alpha_{i t}^{K} s_{i t}
$$

where lowercase letters represent the natural logarithm of their uppercase counterpart, and the shares $\alpha_{i t}^{N}$ and $\alpha_{i t}^{K}$ refer to labor and capital shares in value added. Labor's share in each industry is measured as the nominal compensation of employees divided by nominal value added, and then averaged over the sample period. Capital's share is then computed as a residual:

$$
\alpha_{i t}^{K}=1-\alpha_{i t}^{N}
$$

We examined two filtered versions of the logarithm of the productivity residual, $a_{i t}$. First, we study the growth rate of the productivity residual, employing a simple firstdifference filter, as is commonly done in the productivity literature. Additionally, we examined the cyclical component of the productivity residual using the $\operatorname{BP}_{12}(6,32)$ approximate band-pass filter described in Baxter and King [1999]. We found that the results were similar for the two filters, and we report only the results for the first-difference filter.

with non-energy materials. 


\section{Within-country results}

In this section, we compute sectoral productivity residuals using the various proxies for capital services, and we evaluate the sensitivity of the productivity residuals to alternative assumptions regarding the appropriate utilization proxy.

\subsection{Descriptive statistics}

Table 1 contains the average growth rate of value added, labor and capital inputs, the average product of labor, and three measures of total factor productivity based on our three proxies for capital services. The results are separated into two manufacturing categories: durables and nondurables. Canadian output growth is stronger for both manufacturing groups, with the overall average exceeding the U.S. (2.86 compared to 2.23). U.S. labor input essentially does not grow for durables, and actually has moderately negative growth for nondurables industries. The durables result is driven by the extraordinarily large negative growth in Primary Metals, while the nondurables results are driven by huge declines in labor input for the Tobacco and Leather industries. We see moderate growth in labor input for Canada, with slight negative growth overall for nondurables. This is the same as the U.S. case, where the results are dominated by a large decline in labor input for both the Tobacco and Leather industries. Over the sample period, there is strong growth in fixed capital for both countries. Growth in the average product of labor has been slightly stronger in the U.S., and is stronger for nondurables industries in both countries.

The growth rate of total factor productivity depends upon the particular utilization proxy, and this dependence varies across the two countries. For instance, in the United States, productivity measured using the capital proxy (Solow residual) exhibits the slowest growth for durables, nondurables and overall manufacturing. Overall, we see the largest growth in productivity when capital services is proxied by materials inputs, where U.S. manufacturing productivity grew on average at an average annual rate of $1.61 \%$. This compares with $1.15 \%$ for the capital proxy and $1.41 \%$ for the energy proxy. The three proxies reveal a different pattern for Canadian productivity. In the Canadian data, we find that the materials proxy results in a lower growth rate of productivity for durables and a higher growth rate for nondurables, with the overall effect being an identical average growth rate of productivity across industries when compared to the capital proxy. The main difference for Canada is 
that the energy proxy results in a much lower productivity growth rate for both durables and nondurables: the average growth of productivity across manufacturing industries is $0.66 \%$ - barely half that implied by the capital or materials proxies.

Finally, we examine the correlation of output and factor inputs for each industry in the two countries. Table 2 contains these correlations for both countries. Like Basu [1996], we find that materials displays the largest correlation with output. However, while we find that the correlation of output and materials is greater than the correlation of output and capital input as well as output and energy input, we find that it is roughly equal to that of output and labor input and output and a share-weighted combination of capital and labor input.

\subsection{Standard deviation of productivity by industry}

In this section, we examine the various measures of productivity in terms of their volatility - measured by the standard deviation of the growth rate and cyclical component of each series. A common criticism of the Solow residual is that it is simply too volatile to be an accurate representation of the state of aggregate productivity, and that it implies unrealistic predictions regarding the probability of technical regress. Table 3 contains volatility statistics for each measure of productivity for both the U.S. and Canada.

Canadian productivity is more volatile than that of the U.S. for both durables and nondurables. While the difference is smaller for the materials proxy, this pattern holds across all three proxies for capital services. For durable goods industries, U.S. productivity averages only about $62 \%$ as volatile as Canadian productivity. For the nondurable goods industries, the difference across countries is less pronounced, with U.S. productivity averaging $95 \%$ as volatile as that of Canada. Across all manufacturing, productivity in the U.S. is only $79 \%$ as volatile as in Canada. A second pattern seen in the data is that productivity in nondurable goods industries is more volatile than for durables. ${ }^{7}$ Generally, this holds for both countries. However, the exception to the rule is the productivity series measured using the energy proxy for Canada, where on average it is slightly more volatile for durable goods. Similar patterns exist for both the cyclical component and the growth rate of productivity.

Several industries stand out in terms of volatility. For example, while Furniture

\footnotetext{
${ }^{7}$ This is partially due to the extremely high volatility of productivity in the Petroleum \& Coal sector. For both countries, this industry exhibits roughly double the volatility of any other sector.
} 
and Fixtures productivity displays below-average volatility for the U.S., it displays above-average volatility for Canada. As a result, productivity in this industry is over twice as volatile in Canada than in the U.S.. Similar results are found in Transportation, Electrical Equipment and Miscellaneous Manufacturing. For the nondurables sectors, we see this same pattern for Tobacco, Apparel, Paper, and Rubber and Plastic, where the productivity residuals in Canada are much more volatile than those in the U.S.. In general, we see that the difference (i.e., Canadian relative to U.S.) is greatest for the productivity series measured using materials as the capital services proxy. The opposite is true for Petroleum \& Coal and Leather industries: for Petroleum, each capital services proxy yields approximately the same results, while for Leather the materials proxy delivers the smallest difference between the U.S. and Canada.

The materials and energy proxies reduce the volatility in both countries and in both manufacturing groups; this difference is more pronounced in the durable sectors and is generally strongest for the U.S. In general, the materials proxy produces the least volatile measure of productivity: these measures are roughly $2 / 3$ as volatile as the Solow residual (capital proxy) for durables, and 85\% as volatile for nondurables, with total manufacturing falling in between these two figures. These results are consistent with the idea that materials inputs provide a superior measure of capital services relative to the capital stock. If true capital services are more highly correlated with output fluctuations than the stock of capital, then the capital stock does not provide an accurate estimate of the volatility of the flow of capital services. Any variation in capital services which is not captured by the relatively small variations in the stock of capital is attributed to variations in productivity - thus, overstating the true volatility of total factor productivity. Petroleum seems to be a special case where none of the three proxies provide a sufficient measure of capital services. For both the growth rate and especially the cyclical component, the volatility of productivity for Petroleum \& Coal essentially matches the volatility of output in the industry. The very small variations in labor input and measured capital services relative to output in this industry result in a productivity measure which is essentially identical to output. Additionally, a good portion of the sample period is dominated by erratic movements in value added for this industry, which are the result of the oil price shocks during the 1970's. However, the point being that none of our three proxies appears to do a reasonable job of representing the flow of capital services. 
Table 4 presents a measure of relative volatility - the standard deviation of productivity relative to that of output. This table shows that the Canadian residuals are not only more volatile than US residuals in absolute terms, but are also more volatile relative to own-country output. In the United States, the relative volatility of productivity ranges from $49 \%$ (for materials) to $69 \%$ (for capital proxy), while the corresponding Canadian range is $72-82 \%$, again with materials representing the lowest and capital the greatest. A second clear pattern that emerges is that productivity for nondurables is more volatile relative to output than for the durables sector; this is especially true for the United States, although the same trend holds for Canada.

\subsection{Correlation with output by industry}

Table 5 shows the correlation of output and the productivity residual in each sector. In general, we find that output and the three measures of productivity are highly correlated. Canadian productivity residuals are more highly correlated with output than those in the United States. For both countries, the materials and energy proxies reduce the correlation of productivity and output. This is more pronounced for the United States, with the largest change occurring for the durable goods sectors. Overall, the materials proxy results in the lowest correlation with output. Otherwise, there are similar patterns across non-durables and durables, and there are no significant differences for the growth rate and cyclical component.

\subsection{Correlation with labor input by industry}

Because labor input and capital services are complements in production, increases in labor input and capital services should coincide. For example, during an economic boom, increases in hours worked cause subsequent increases in the marginal product of capital services, resulting in increased capital accumulation and/or greater utilization of the capital stock. A measure of productivity which does not account for cyclical movements in the utilization of capital will cause labor input to be artificially correlated with productivity.

Table 6 contains the correlation of labor input, measured by hours worked, and the three measures of the productivity residual. Generally, we find the productivitylabor input correlations to be lower than those between productivity and output. The largest correlations are found for the capital proxy, and these correlations are greater 
for the durables sectors for both the cyclical component and the growth rate. For both countries, the productivity-labor input correlations are reduced when the materials and energy proxies are employed. In fact, the materials proxy nearly reduces the correlation to zero. For productivity growth rates, there is still a large difference in this correlation across the durables and nondurables sectors.

\section{Cross-country, cross-industry behavior of pro- ductivity}

This section studies the cross-country, cross-industry behavior of productivity. We want to learn how altering the measure of capital utilization changes our view of the correlation of productivity innovations across industries, within and across countries. We also explore how alternative measures of productivity affect estimates of the parameters of the stochastic process for productivity across countries.

\subsection{Correlation across industries and across countries}

Our main results are summarized in Table 7. This table displays the cross-country correlation of productivity within an industry and the correlation of productivity across industries within a country. Panel 1 of the table focuses on intra-industry, cross-country correlations; these correlations are also displayed in Figures 1-A and 1B. These correlations give an idea of how correlated productivity is across countries when focusing on a single industry. For example, the correlation of productivity growth is 0.35 between the US and Canadian Lumber \& Wood industries when the capital stock is used as the measure of capital services. This correlation falls to 0.17 when materials are used as the proxy for capital services, and is 0.27 when energy is used. Taken as a group, the durables sectors display higher intra-industry, crosscountry correlations than do the nondurables sectors. This is true for each of the proxies for capital services. For example, when materials are used as the capital proxy the average intra-industry, cross-country correlation for durables is 0.26 , but is only 0.17 for nondurables. When energy is used, the correlation is 0.38 for durables, but 0.26 for nondurables. For most individual industries, the capital proxy yields the highest intra-industry, cross-country correlation, while the materials proxy yields the lowest correlation. 
It is difficult to know what to make of these intra-industry, cross-country correlations without some kind of benchmark. The lower part of Table 7 shows the average correlation between industries within the US and within Canada. The typical correlation across US industries is 0.38 with the capital stock proxy; the Canadian correlation is 0.30 . These within-country correlations drop to the 0.24-0.29 range with the materials and energy proxies. Thus we conclude that intra-industry, crosscountry correlations are of similar magnitude to the typical cross-industry correlation within a country.

Panel 4 of Table 7 displays the average correlation between industries across countries. This correlation is computed as the average of all correlations formed by using one industry in the US and another industry in Canada. This should be thought of as a 'typical' cross-country correlation, where the industry is not necessarily the same across countries. Here, we find that the correlation is lower than the intra-industry, cross-country correlations reported in Panel 1. That is: cross-country correlations are higher when the industry in question is the same in both countries. This is true regardless of the proxy for capital services. We also observe that the average correlation across countries is lower than the average within a country; again, this is true for

all measures of capital services. These results suggest that there are country-specific components to productivity as well as industry-specific components to productivity, and that this finding is robust to the particular measure of labor services.

\subsection{Statistical models of productivity}

Two-country real business cycle models typically specify a bivariate process for productivity of the following form:

$$
\left[\begin{array}{l}
a_{t} \\
a_{t}^{*}
\end{array}\right]=\left[\begin{array}{cc}
\rho & \nu^{*} \\
\nu & \rho^{*}
\end{array}\right]\left[\begin{array}{l}
a_{t-1} \\
a_{t-1}^{*}
\end{array}\right]+\left[\begin{array}{c}
\varepsilon_{t} \\
\varepsilon_{t}^{*}
\end{array}\right],
$$

where $a_{t}$ represents the logarithm of productivity in the home country, $a_{t}^{*}$ is the same for the foreign country, and $\operatorname{corr}\left(\varepsilon_{t}, \varepsilon_{t}^{*}\right)>0$. The diagonal terms $\left(\rho, \rho^{*}\right)$ indicate the degree of persistence in productivity, and the off-diagonal terms $\left(\nu, \nu^{*}\right)$ represent cross-country, intertemporal spillover of productivity innovations. Previous research has revealed these parameters to be very difficult to estimate with precision. The estimates of Backus, Kehoe and Kydland [1992] suggest that innovations to productivity are temporary and that there are large, positive spillovers between countries. 
However, they use output and labor input to construct their measures of productivity, which ignores important movements associated with capital services. Using a dataset on aggregate output for several countries, together with measures of labor and capital services, Reynolds [1993] finds that if spillovers exist, they are not symmetric across countries. Baxter and Crucini [1995] use the Backus, et al. data and methodology, and find that it is not possible to reject the existence of a unit root in productivity. More specifically, they cannot reject the hypothesis that productivity is well described by an independent random walk in each country. The imprecision of these parameter estimates is troubling, given that they play such an important role in open-economy business cycle models.

We estimate versions of (5) for three aggregated measures of productivity: nondurables, durables and total manufacturing. We compare the estimates for each productivity measure using our three proxies for capital services. The results are presented in Table 8. The estimated persistence parameters for each utilization proxy exceed 0.95 for most cases; given the size of the standard errors, statistical tests would not reject a hypothesis of a unit root. At the aggregate level, the materials and energy proxies produce a more persistent productivity series. For the durable goods industries, this effect is less evident for the materials proxy and more apparent for the energy proxy.

We find little evidence in favor of intertemporal cross-country spillovers of productivity. Estimates of (5) indicate that there are few cases where even one of the spillover parameters is statistically significant. Additionally, the few spillover parameters that are marginally statistically significant are negative, which is implausible, as it implies that technical progress in one country leads, over time, to technical regress in the other.

Two alternative methods of exploring the spillover question are to examine leadlag relationships of productivity across countries and to test for Granger causality. If productivity correlations within an industry leads in one country, then there is some evidence in favor of spillover. Similarly, Granger causality of productivity across countries would suggest intertemporal cross-country spillover. We examined both of these and still found no evidence to support the spillover hypothesis. 


\section{Conclusion}

This paper studies the impact of variations in factor utilization on the measurement of productivity and its statistical properties, both within and across countries. Using sectoral data for the United States and Canada, we examined the properties of the productivity residual based on three proxies for capital services: the capital stock; materials inputs, and energy usage. In both countries, we found that accounting for variable capital utilization alters many of the empirical characteristics of productivity residuals.

After accounting for variations in capital utilization, productivity appears much less volatile, and displays much lower correlations with output and labor input. While these results initially seem troublesome for real business cycle models, recent research indicates that this is not necessarily the case. King and Rebelo [1998] and Baxter and Farr [2001] show that productivity shocks need not be extremely volatile to mimic the patterns of business cycles. Both papers develop models that generate realistic business cycles when driven by a productivity series which is roughly $60 \%$ as volatile as output and displays very low probability of technical regress. Additionally, the model of Baxter and Farr [2001] indicates that variable capital utilization actually improves the ability of an open economy real business cycle model to replicate common cyclical patterns without an extremely volatile productivity process and without unreasonably large correlations of productivity with output, labor input, or across countries.

We found that accounting for variations in factor utilization rates reduces the correlation of productivity across countries within a given sector. More importantly, we found that the correlation of these intra-industry, cross-country productivity shocks exceeds the average cross-country correlation (where the average is taken over all possible industry pairs). This suggests that there are important industry-specific components to productivity that can be detected even in short time series using annual data, and which are robust to various proxies for capital services. Further, we found that the average correlation across industries within a particular country was similar for the US and Canada, and exceeded the average cross-country correlation.

We found that estimates of a bivariate process for productivity are not affected significantly by alternative proxies for capital services. Productivity is highly persistent in each country and may contain a unit root. Our results offer no support for

the existence of significant intertemporal cross-country spillover of productivity inno- 
vations. Unfortunately, accounting for variable capital utilization does not lead to greater precision in the parameter estimates. Thus, significant uncertainty remains concerning the true stochastic process for productivity. 


\section{References}

[1] Backus, David, Patrick Kehoe and Finn Kydland [1992], "International Real Business Cycles," Journal of Political Economy 101, 745-775.

[2] Balassa, Bela [1964], "The Purchasing Power Parity Doctrine: A Reappraisal," Journal of Political Economy 72, 584-596.

[3] Basu, Susanto [1996], "Procyclical Productivity: Increasing Returns or Cyclical Utilization?" Quarterly Journal of Economics 111, 719-751.

[4] Basu, Susanto and John G. Fernald [1995], "Aggregate Productivity and the Productivity of Aggregates," NBER working paper no. 5382.

[5] Basu, Susanto and Miles S. Kimball [1997], "Cyclical Productivity with Unobserved Input Variation," NBER working paper no. 5915.

[6] Baxter, Marianne and Mario J. Crucini [1995], "Business Cycles and the Asset Structure of Foreign Trade," International Economic Review 36, 821-854.

[7] Baxter, Marianne and Dorsey D. Farr [2001], "Variable Factor Utilization and International Business Cycles," NBER Working Paper \#8392, July 2001.

[8] Baxter, Marianne and Robert G. King [1999], "Measuring Business Cycles: Approximate Band Pass Filters for Economic Time Series," Review of Economics and Statistics 81:4, November 1999, 575-593.

[9] Burnside, Craig, Martin Eichenbaum and Sergio Rebelo [1995], "Capital Utilization and Returns to Scale," in Bernanke and Rotemberg, eds., NBER Macroeconomics Annual 1995, Cambridge: MIT Press.

[10] Costello, Donna M. [1993], "A Cross-Country, Cross-Industry Comparison of Productivity Growth," Journal of Political Economy 101, 207-222.

[11] Evans, Charles L. [1992], "Productivity Shocks and Real Business Cycles," Journal of Monetary Economics 29, 191-208.

[12] Hall, Robert E. [1988], "The Relation Between Price and Marginal Cost in U.S. Industry," Journal of Political Economy 96, 921-47. 
[13] Jorgenson, Dale W. [1995], "Productivity and Economic Growth," in Jorgenson, ed. Productivity Volume 2: International Comparisons of Economic Growth, Cambridge: MIT Press.

[14] Jorgenson, Dale W. and Zvi Grilliches [1967], "The Explanation of Productivity Change," Review of Economic Studies 34, 249-283.

[15] King, Robert G. and Sergio Rebelo [1998], "Resuscitating Real Business Cycles," in Taylor and Woodford eds., Handbook of Macroeconomics, Elsevier: North Holland.

[16] Prescott, Edward C. [1986], "Theory Ahead of Business Cycle Measurement," Carnegie-Rochester Conference Series on Public Policy 15, 11-44.

[17] Reynolds, Patricia [1993], "International Comovements in Aggregate Productivity: An Empirical Analysis," working paper, University of Southern California.

[18] Samuelson, Paul A. [1964], "Theoretical Notes on Trade Problems," Review of Economics and Statistics 46, 145-154.

[19] Shapiro, Matthew D. [1993], "Cyclical Productivity and the Workweek of Capital," American Economic Review, Papers and Proceedings 83, 229-233.

[20] Shapiro, Matthew D. [1996], "Macroeconomic Implications of Variation in the Workweek of Capital," Brookings Papers on Economic Activity 2, 79-119.

[21] Solow, Robert M. [1957], "Technical Change and the Aggregate Production Function," 39, 312-320.

[22] Tinbergen, Jan [1942], "Zur Theorie der Langfristigen Wirtschaftsentwicklung," Weltwirtschaftliches Archiv 55, 511-549; English translation [1959], "On the Theory of Trend Movements," in Jan Tinbergen, Selected Papers, Klaassen, Koyck, and Witteveen, eds., Elsevier: North Holland. 


\section{Appendix}

This appendix discusses the data used for the empirical analysis. Our data comes from four main sources - two for each country. The data for the United States comes from the NBER Productivity Database (also known as the ASM Database) and Citibase. Output, which we measure as using value added, is found in both real and nominal dollars. Labor input is measured by the total hours worked by production workers, also found in the $A S M$. To compute labor's share, we used a measure of total compensation from Citibase. Using this series, which is in current dollars, and the measure of nominal value added from the $A S M$, we computed a measure of labor's share. Capital's share is then computed as a residual. Energy and materials inputs are measured by the real value of spending on each, where materials spending includes purchases of energy materials as well as other materials. The results are not much different if we only use the non-energy component of materials inputs. For Canada, the data come from the Canadian Input-Output Tables and the KLEMS Database. Each measure is similar to that of the United States, with the exception of labor's share, which is measured using a compensation series for production workers. However, the resulting share statistics are quite similar. 
Table 1: Annual growth rates of output, factor inputs, and productivity

\begin{tabular}{|c|c|c|c|c|c|c|c|}
\hline 1. U.S. & VA & $\mathrm{N}$ & $\mathrm{K}$ & APL & AK & AM & $\mathrm{AE}$ \\
\hline Lumber \& Wood & 1.82 & 0.06 & 1.79 & 1.76 & 1.19 & 1.04 & 1.09 \\
\hline Furniture \& Fixtures & 2.59 & 0.65 & 3.54 & 1.94 & 0.88 & 1.27 & 1.06 \\
\hline Stone, Clay \& Glass & 1.09 & -0.62 & 1.45 & 1.71 & 0.87 & 1.05 & 1.26 \\
\hline Primary Metals & -0.27 & -1.47 & 0.75 & 1.20 & 0.45 & 0.60 & 0.66 \\
\hline Fabricated Metals & 1.85 & 0.46 & 3.16 & 1.39 & 0.36 & 0.85 & 0.60 \\
\hline Industrial Machinery & 2.85 & 0.35 & 4.06 & 2.50 & 1.08 & 1.36 & 1.63 \\
\hline Electrical Equipment & 4.58 & 0.50 & 5.01 & 4.08 & 2.88 & 3.22 & 3.36 \\
\hline Transportation Equipment & 2.29 & -0.17 & 2.25 & 2.46 & 1.62 & 1.62 & 1.71 \\
\hline Misc. Manufacturing & 4.29 & 0.39 & 4.97 & 3.90 & 1.40 & 2.25 & 2.05 \\
\hline Average across durables & 2.34 & 0.02 & 3.00 & 2.33 & 1.19 & 1.47 & 1.49 \\
\hline Food & 2.39 & -0.27 & 2.20 & 2.66 & 1.28 & 1.66 & 1.54 \\
\hline Tobacco & 1.89 & -3.09 & 4.34 & 4.98 & -0.62 & 3.38 & 0.22 \\
\hline Apparel & 2.12 & -1.23 & 1.38 & 3.35 & 2.40 & 2.20 & 2.11 \\
\hline Textiles & 1.94 & -0.95 & 2.67 & 2.89 & 1.50 & 2.11 & 1.74 \\
\hline Paper & 2.94 & 0.24 & 3.85 & 2.71 & 1.06 & 1.68 & 1.62 \\
\hline Printing \& Publishing & 2.25 & 0.47 & 3.27 & 1.78 & 0.47 & 0.96 & 0.09 \\
\hline Chemicals & 3.61 & 0.18 & 2.75 & 3.43 & 1.82 & 1.65 & 2.17 \\
\hline Petroleum \& Coal & 1.63 & -0.88 & 1.65 & 2.51 & 1.23 & 0.82 & 1.05 \\
\hline Rubber \& Plastic & 4.65 & 2.49 & 4.39 & 2.16 & 1.31 & 1.47 & 1.38 \\
\hline Leather & -2.10 & -4.21 & 0.17 & 2.11 & 0.70 & 1.38 & 1.40 \\
\hline Average across nondurables & 2.13 & -0.72 & 2.67 & 2.86 & 1.12 & 1.73 & 1.33 \\
\hline Average across all manufacturing & 2.23 & -0.37 & 2.82 & 2.61 & 1.15 & 1.61 & 1.41 \\
\hline 2. Canada & VA & $\mathrm{N}$ & $\mathrm{K}$ & APL & AK & AM & $\mathrm{AE}$ \\
\hline Lumber \& Wood & 3.50 & 0.54 & 3.62 & 2.96 & 2.10 & 2.11 & 1.53 \\
\hline Furniture \& Fixtures & 2.03 & 1.30 & 2.40 & 0.74 & 0.44 & 0.13 & -0.33 \\
\hline Stone, Clay \& Glass & 1.83 & 0.18 & 2.06 & 1.65 & 0.84 & 0.61 & 0.21 \\
\hline Primary Metals & 2.37 & -0.04 & 3.62 & 2.41 & 1.01 & 1.47 & 0.51 \\
\hline Fabricated Metals & 2.76 & 1.23 & 2.27 & 1.52 & 1.17 & 0.98 & 0.23 \\
\hline Industrial Machinery & 2.84 & 1.93 & 3.90 & 0.91 & 0.23 & 0.05 & -0.35 \\
\hline Electrical Equipment & 6.19 & 0.86 & 4.97 & 5.33 & 3.87 & 2.46 & 3.94 \\
\hline Transportation Equipment & 6.43 & 2.34 & 5.32 & 4.09 & 3.03 & 2.78 & 2.56 \\
\hline Misc. Manufacturing & 2.91 & 1.16 & 4.53 & 1.75 & 0.70 & 0.97 & 0.42 \\
\hline Average across durables & 3.43 & 1.06 & 3.63 & 2.37 & 1.49 & 1.28 & 0.97 \\
\hline Food & 2.00 & -0.12 & 3.02 & 2.11 & 0.71 & 1.00 & 0.10 \\
\hline Tobacco & 0.05 & -3.11 & 1.74 & 3.15 & 0.42 & 1.63 & -0.44 \\
\hline Apparel & 3.56 & -0.95 & 0.20 & 4.50 & 4.10 & 3.11 & 2.68 \\
\hline Textiles & 1.39 & -0.67 & 0.33 & 2.07 & 1.82 & 1.28 & 0.81 \\
\hline Paper & 1.42 & 0.16 & 4.48 & 1.25 & -0.61 & -0.12 & -0.89 \\
\hline Printing \& Publishing & 2.51 & 1.61 & 3.74 & 0.91 & 0.23 & 0.14 & -0.36 \\
\hline Chemicals & 4.46 & 1.10 & 5.21 & 3.36 & 1.37 & 1.80 & 1.14 \\
\hline Petroleum \& Coal & 3.52 & 0.14 & 3.33 & 3.38 & 0.42 & 1.30 & -1.28 \\
\hline Rubber \& Plastic & 5.87 & 3.33 & 4.75 & 2.55 & 2.02 & 1.64 & 0.96 \\
\hline Leather & -1.22 & -3.33 & 0.81 & 2.10 & 1.15 & 1.68 & 1.07 \\
\hline Average across nondurables & 2.35 & -0.18 & 2.76 & 2.54 & 1.16 & 1.35 & 0.38 \\
\hline Average across all manufacturing & 2.86 & 0.40 & 3.17 & 2.46 & 1.32 & 1.32 & 0.66 \\
\hline
\end{tabular}

Notes: All statistics are in percentage terms. Variables are defined as follows: VA is value added; $\mathrm{K}$ is the capital stock; N is labor input (hours worked); APL is the average product of labor; AK is total factor productivity constructed using the capital stock; AM is total factor productivity constructed using materials inputs; $A E$ is total factor productivity constructed using energy inputs. 
Table 2: Average Correlation of Output and Factor Inputs

\begin{tabular}{lccccc}
\hline & & & & & $\begin{array}{c}\text { Labor- } \\
\text { Capital } \\
\text { Growth Rate }\end{array}$ \\
\cline { 2 - 6 } & Labor & Capital & Materials & Energy & $\begin{array}{c}\text { Aggregate } \\
\text { U.S. }\end{array}$ \\
\cline { 2 - 6 } Canada & 0.77 & 0.10 & 0.77 & 0.47 & 0.70 \\
Cyclical Component (band-pass filter) & & 0.71 & 0.53 & 0.60 \\
U.S. & 0.77 & -0.01 & 0.79 & 0.49 & 0.71 \\
Canada & 0.61 & -0.13 & 0.68 & 0.57 & 0.54 \\
\hline \hline
\end{tabular}

Note. Statistics in the table are the cross-industry average of the correlation between output and each factor input variable. 
Table 3: Productivity growth rate

\begin{tabular}{|c|c|c|c|c|c|c|c|c|c|c|}
\hline & \multicolumn{6}{|c|}{ Standard deviation of productivity by industry } & \multicolumn{4}{|c|}{ Percent reductions in volatility } \\
\hline & \multicolumn{2}{|c|}{ Capital } & \multicolumn{2}{|c|}{ Materials } & \multicolumn{2}{|c|}{ Energy } & \multicolumn{2}{|c|}{ Materials } & \multicolumn{2}{|c|}{ Energy } \\
\hline & U.S. & Canada & U.S. & Canada & U.S. & Canada & U.S. & Canada & U.S. & Canada \\
\hline Lumber \& Wood & 5.11 & 5.75 & 3.94 & 4.97 & 3.97 & 5.49 & 0.23 & 0.14 & 0.22 & 0.05 \\
\hline Furniture \& Fixtures & 3.49 & 8.17 & 2.18 & 7.20 & 2.64 & 7.39 & 0.38 & 0.12 & 0.24 & 0.10 \\
\hline Stone, Clay \& Glass & 4.32 & 7.23 & 2.37 & 4.85 & 3.23 & 5.38 & 0.45 & 0.33 & 0.25 & 0.26 \\
\hline Primary Metals & 7.61 & 8.03 & 4.77 & 6.78 & 6.05 & 6.68 & 0.37 & 0.16 & 0.20 & 0.17 \\
\hline Fabricated Metals & 3.49 & 4.27 & 2.18 & 3.09 & 3.09 & 3.67 & 0.38 & 0.28 & 0.11 & 0.14 \\
\hline Industrial Machinery & 4.81 & 6.72 & 2.69 & 4.08 & 4.24 & 6.16 & 0.44 & 0.39 & 0.12 & 0.08 \\
\hline Electrical Equipment & 2.67 & 6.08 & 1.94 & 4.85 & 2.38 & 5.57 & 0.27 & 0.20 & 0.11 & 0.08 \\
\hline Transportation Equipment & 4.73 & 9.36 & 2.80 & 6.19 & 4.10 & 7.52 & 0.41 & 0.34 & 0.13 & 0.20 \\
\hline Misc. Manufacturing & 3.00 & 5.36 & 2.42 & 5.04 & 3.01 & 5.19 & 0.19 & 0.06 & 0.00 & 0.03 \\
\hline Average across durables & 4.36 & 6.77 & 2.81 & 5.23 & 3.63 & 5.89 & 0.36 & 0.23 & 0.17 & 0.13 \\
\hline Food & 3.36 & 3.21 & 2.99 & 3.05 & 3.69 & 3.19 & 0.11 & 0.05 & -0.10 & 0.01 \\
\hline Tobacco & 3.66 & 7.99 & 4.27 & 12.10 & 4.94 & 7.86 & -0.17 & -0.51 & -0.35 & 0.02 \\
\hline Apparel & 3.74 & 7.45 & 2.69 & 5.17 & 3.25 & 5.92 & 0.28 & 0.31 & 0.13 & 0.21 \\
\hline Textiles & 3.20 & 3.49 & 2.37 & 3.20 & 3.16 & 3.58 & 0.26 & 0.08 & 0.01 & -0.03 \\
\hline Paper & 4.41 & 7.44 & 3.12 & 5.21 & 3.80 & 4.53 & 0.29 & 0.30 & 0.14 & 0.39 \\
\hline Printing \& Publishing & 3.31 & 4.03 & 2.34 & 3.08 & 3.63 & 3.44 & 0.29 & 0.24 & -0.10 & 0.15 \\
\hline Chemicals & 6.26 & 6.35 & 4.30 & 4.88 & 5.98 & 5.86 & 0.31 & 0.23 & 0.04 & 0.08 \\
\hline Petroleum \& Coal & 17.02 & 10.27 & 17.07 & 10.88 & 17.12 & 10.72 & 0.00 & -0.06 & -0.01 & -0.04 \\
\hline Rubber \& Plastic & 4.93 & 7.41 & 2.97 & 5.85 & 3.91 & 6.29 & 0.40 & 0.21 & 0.21 & 0.15 \\
\hline Leather & 5.07 & 4.23 & 4.85 & 3.35 & 4.95 & 3.93 & 0.04 & 0.21 & 0.02 & 0.07 \\
\hline Average across nondurables & 5.50 & 6.19 & 4.70 & 5.68 & 5.44 & 5.53 & 0.15 & 0.08 & 0.01 & 0.11 \\
\hline Average across all manufacturing & 4.96 & 6.47 & 3.80 & 5.46 & 4.59 & 5.70 & 0.23 & 0.15 & 0.07 & 0.12 \\
\hline
\end{tabular}

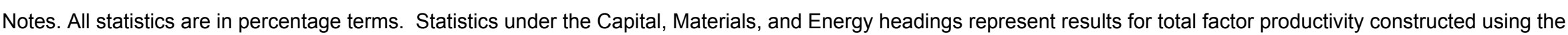
capital stock, materials inputs, and energy inputs, respectively. 
Table 4: Relative Volatility Standard deviation of productivity growth relative to standard devation of output growth

\begin{tabular}{|c|c|c|c|c|c|c|}
\hline & \multicolumn{2}{|c|}{ Capital } & \multicolumn{2}{|c|}{ Materials } & \multicolumn{2}{|c|}{ Energy } \\
\hline & U.S. & Canada & U.S. & Canada & U.S. & Canada \\
\hline Lumber \& Wood & 0.65 & 0.64 & 0.50 & 0.56 & 0.50 & 0.61 \\
\hline Furniture \& Fixtures & 0.46 & 0.80 & 0.29 & 0.70 & 0.35 & 0.72 \\
\hline Stone, Clay \& Glass & 0.65 & 0.73 & 0.36 & 0.49 & 0.48 & 0.55 \\
\hline Primary Metals & 0.60 & 0.87 & 0.37 & 0.74 & 0.48 & 0.73 \\
\hline Fabricated Metals & 0.49 & 0.57 & 0.31 & 0.41 & 0.44 & 0.49 \\
\hline Industrial Machinery & 0.55 & 0.63 & 0.31 & 0.38 & 0.49 & 0.57 \\
\hline Electrical Equipment & 0.35 & 0.74 & 0.26 & 0.59 & 0.32 & 0.68 \\
\hline Transportation Equipment & 0.54 & 0.79 & 0.32 & 0.52 & 0.47 & 0.63 \\
\hline Misc. Manufacturing & 0.65 & 0.86 & 0.52 & 0.81 & 0.65 & 0.84 \\
\hline Average across durables & 0.55 & 0.74 & 0.36 & 0.58 & 0.46 & 0.65 \\
\hline Food & 1.00 & 0.92 & 0.89 & 0.87 & 1.10 & 0.91 \\
\hline Tobacco & 1.00 & 1.04 & 1.16 & 1.57 & 1.34 & 1.02 \\
\hline Apparel & 0.59 & 0.80 & 0.43 & 0.56 & 0.51 & 0.64 \\
\hline Textiles & 0.66 & 0.70 & 0.49 & 0.64 & 0.65 & 0.72 \\
\hline Paper & 0.77 & 0.82 & 0.54 & 0.57 & 0.66 & 0.50 \\
\hline Printing \& Publishing & 0.71 & 0.91 & 0.50 & 0.69 & 0.78 & 0.77 \\
\hline Chemicals & 0.96 & 0.96 & 0.66 & 0.73 & 0.92 & 0.88 \\
\hline Petroleum \& Coal & 1.01 & 0.96 & 1.01 & 1.02 & 1.02 & 1.00 \\
\hline Rubber \& Plastic & 0.60 & 0.82 & 0.36 & 0.65 & 0.47 & 0.70 \\
\hline Leather & 0.75 & 0.56 & 0.71 & 0.44 & 0.73 & 0.52 \\
\hline Average across nondurables & 0.81 & 0.85 & 0.68 & 0.77 & 0.82 & 0.77 \\
\hline Average across all manufacturing & 0.68 & 0.80 & 0.53 & 0.68 & 0.65 & 0.71 \\
\hline
\end{tabular}

Notes. Statistics under the Capital, Materials, and Energy headings represent results for total factor productivity constructed using the capital stock, materials inputs, and energy inputs, respectively. 
Table 5: Correlation of productivity and output by industry

\begin{tabular}{|c|c|c|c|c|c|c|}
\hline & \multicolumn{2}{|c|}{ Capital } & \multicolumn{2}{|c|}{ Materials } & \multicolumn{2}{|c|}{ Energy } \\
\hline & U.S. & Canada & U.S. & Canada & U.S. & Canada \\
\hline Lumber \& Wood & 0.79 & 0.82 & 0.49 & 0.58 & 0.49 & 0.60 \\
\hline Furniture \& Fixtures & 0.92 & 0.88 & 0.58 & 0.75 & 0.68 & 0.79 \\
\hline Stone, Clay \& Glass & 0.92 & 0.97 & 0.66 & 0.87 & 0.73 & 0.86 \\
\hline Primary Metals & 0.95 & 0.94 & 0.79 & 0.81 & 0.82 & 0.83 \\
\hline Fabricated Metals & 0.90 & 0.88 & 0.50 & 0.57 & 0.73 & 0.76 \\
\hline Industrial Machinery & 0.89 & 0.94 & 0.55 & 0.63 & 0.83 & 0.79 \\
\hline Electrical Equipment & 0.72 & 0.90 & 0.06 & 0.67 & 0.58 & 0.79 \\
\hline Transportation Equipment & 0.87 & 0.94 & 0.25 & 0.82 & 0.76 & 0.86 \\
\hline Misc. Manufacturing & 0.90 & 0.89 & 0.27 & 0.78 & 0.65 & 0.67 \\
\hline Average across durables & 0.87 & 0.91 & 0.46 & 0.72 & 0.70 & 0.77 \\
\hline Food & 0.95 & 0.95 & 0.84 & 0.89 & 0.85 & 0.74 \\
\hline Tobacco & 0.73 & 0.95 & 0.68 & 0.74 & 0.65 & 0.79 \\
\hline Apparel & 0.82 & 0.94 & 0.53 & 0.85 & 0.45 & 0.87 \\
\hline Textiles & 0.83 & 0.85 & 0.73 & 0.60 & 0.57 & 0.64 \\
\hline Paper & 0.92 & 0.96 & 0.78 & 0.91 & 0.75 & 0.88 \\
\hline Printing \& Publishing & 0.75 & 0.89 & 0.08 & 0.77 & 0.48 & 0.73 \\
\hline Chemicals & 0.95 & 0.93 & 0.69 & 0.88 & 0.69 & 0.77 \\
\hline Petroleum \& Coal & 0.99 & 0.97 & 0.97 & 0.88 & 0.96 & 0.90 \\
\hline Rubber \& Plastic & 0.91 & 0.94 & 0.48 & 0.85 & 0.74 & 0.86 \\
\hline Leather & 0.81 & 0.89 & 0.64 & 0.69 & 0.7 & 0.71 \\
\hline Average across nondurables & 0.87 & 0.93 & 0.64 & 0.81 & 0.68 & 0.79 \\
\hline Average across all manufacturing & 0.87 & 0.92 & 0.56 & 0.77 & 0.69 & 0.78 \\
\hline
\end{tabular}

Notes. Statistics under the Capital, Materials, and Energy headings represent results for total factor productivity constructed using the capital stock, materials inputs, and energy inputs, respectively. 
Table 6: Correlation of productivity and labor input by industry

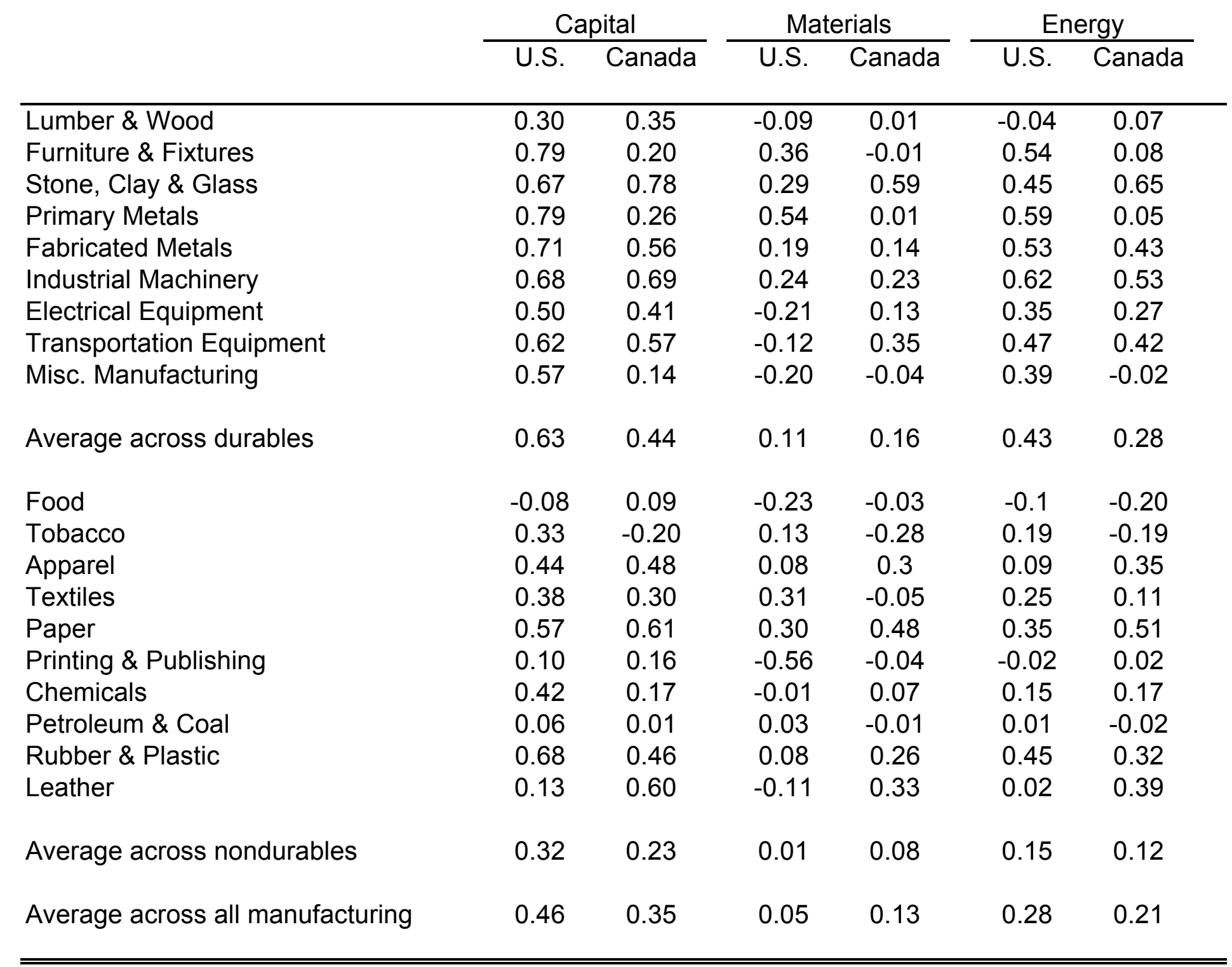

Notes. Statistics under the Capital, Materials, and Energy headings represent results for total factor productivity constructed using the capital stock, materials inputs, and energy inputs, respectively. 
Table 7: Correlation of productivity within and across countries

Capital Materials Energy

1. Intra-industry cross-country correlations

\begin{tabular}{|c|c|c|c|}
\hline Lumber \& Wood & 0.35 & 0.17 & 0.27 \\
\hline Furniture \& Fixtures & 0.55 & 0.31 & 0.33 \\
\hline Stone, Clay \& Glass & 0.76 & 0.54 & 0.57 \\
\hline Primary Metals & 0.64 & 0.41 & 0.40 \\
\hline Fabricated Metals & 0.62 & 0.33 & 0.48 \\
\hline Industrial Machinery & 0.58 & -0.01 & 0.31 \\
\hline Electrical Equipment & 0.52 & 0.21 & 0.50 \\
\hline Transportation Equipment & 0.52 & -0.02 & 0.24 \\
\hline Misc. Manufacturing & 0.60 & 0.43 & 0.28 \\
\hline Average across durables & 0.57 & 0.26 & 0.38 \\
\hline Food & 0.17 & 0.08 & 0.28 \\
\hline Tobacco & 0.08 & 0.18 & 0.05 \\
\hline Apparel & 0.33 & -0.10 & 0.28 \\
\hline Textiles & 0.16 & 0.24 & 0.33 \\
\hline Paper & 0.75 & 0.50 & 0.55 \\
\hline Printing \& Publishing & 0.43 & 0.22 & 0.16 \\
\hline Chemicals & 0.79 & 0.42 & 0.47 \\
\hline Petroleum \& Coal & 0.09 & -0.10 & -0.14 \\
\hline Rubber \& Plastic & 0.56 & 0.20 & 0.48 \\
\hline Leather & 0.03 & 0.07 & 0.09 \\
\hline Average across nondurables & 0.34 & 0.17 & 0.26 \\
\hline Average across all manufacturing & 0.45 & 0.21 & 0.31 \\
\hline verage across U.S. industries & 0.38 & 0.24 & 0.29 \\
\hline verage across Canadian industries & 0.39 & 0.27 & 0.26 \\
\hline verage across countries & 0.25 & 0.09 & 0.13 \\
\hline
\end{tabular}

Notes. Statistics under the Capital, Materials, and Energy headings represent results for total factor productivity constructed using the capital stock, materials inputs, and energy inputs, respectively. 
Table 8. Productivity persistence and spillover

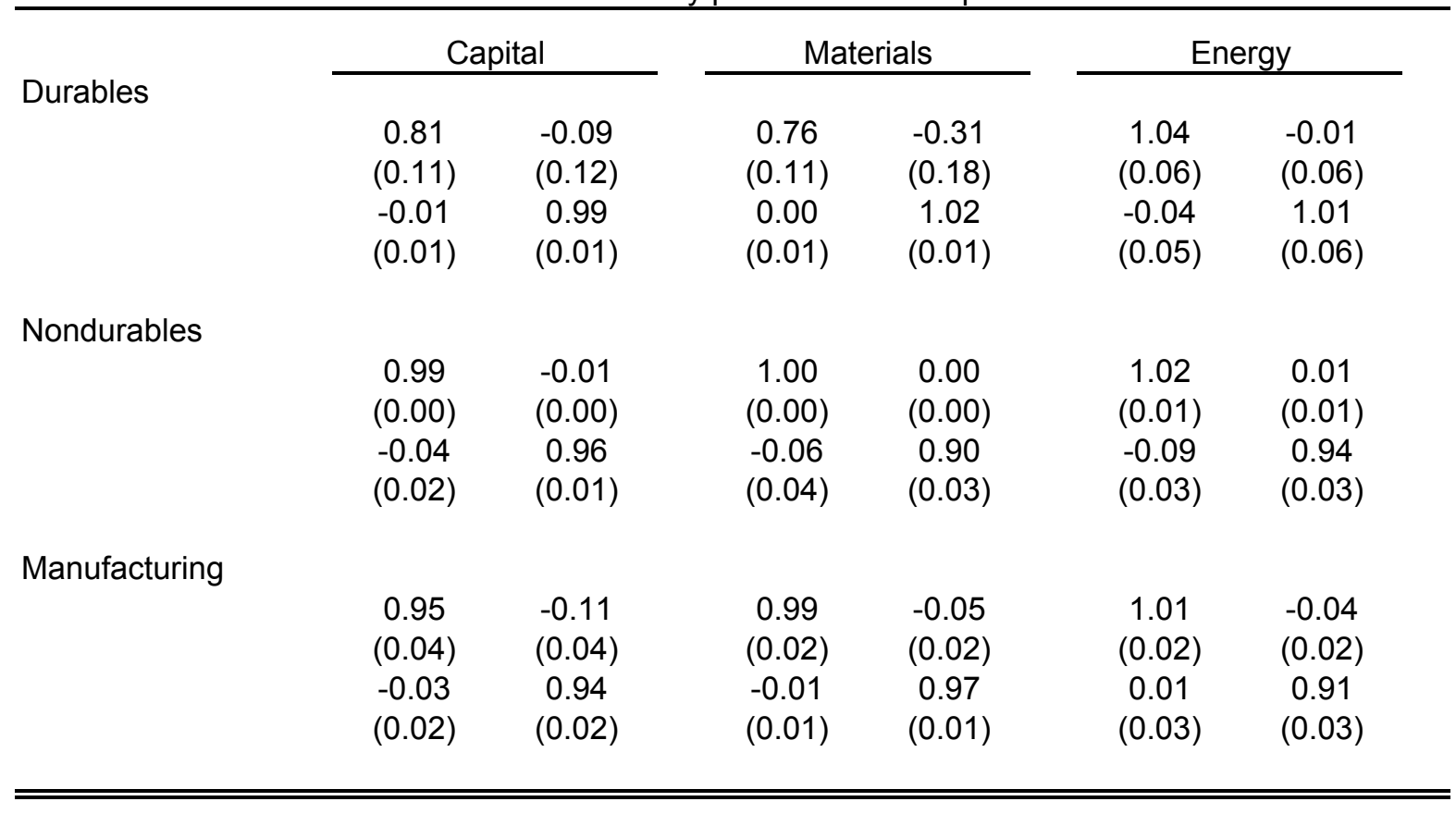

Notes. Estimates correspond to equation (3.5), with the first column containing the estimates from the equation for the Canadian productivity residual and the second column containing the estimates from the equation for the U.S. productivity residual. Standard errors in parentheses. Statistics under the Capital, Materials, and Energy headings represent results for total factor productivity constructed using the capital stock, materials inputs, and energy inputs, respectively. 
Figure 1-A: Durable goods: Intra-industry, cross-country correlations

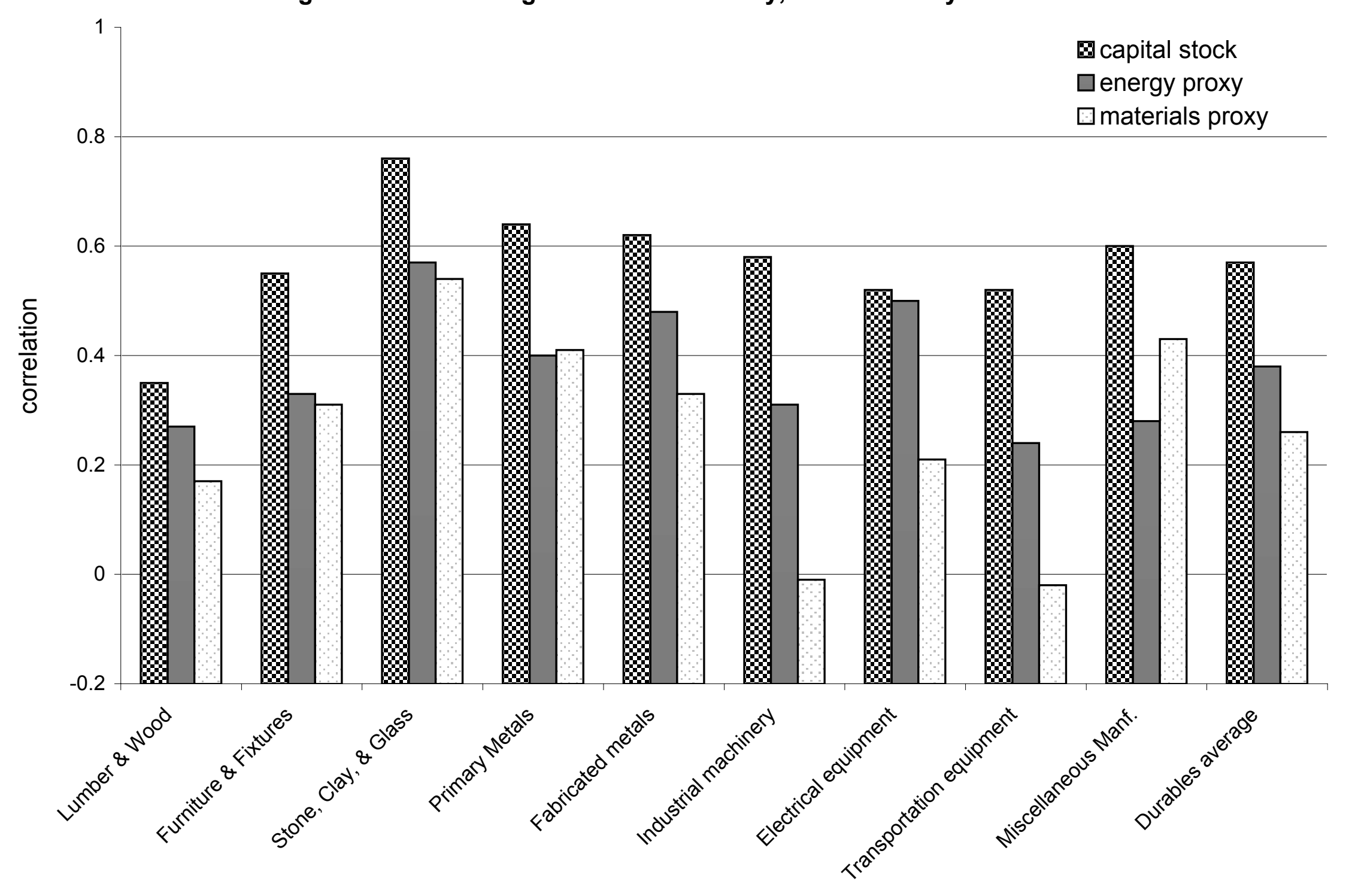


Figure 1-B: Nondurable goods: Intra-industry, cross-country correlations

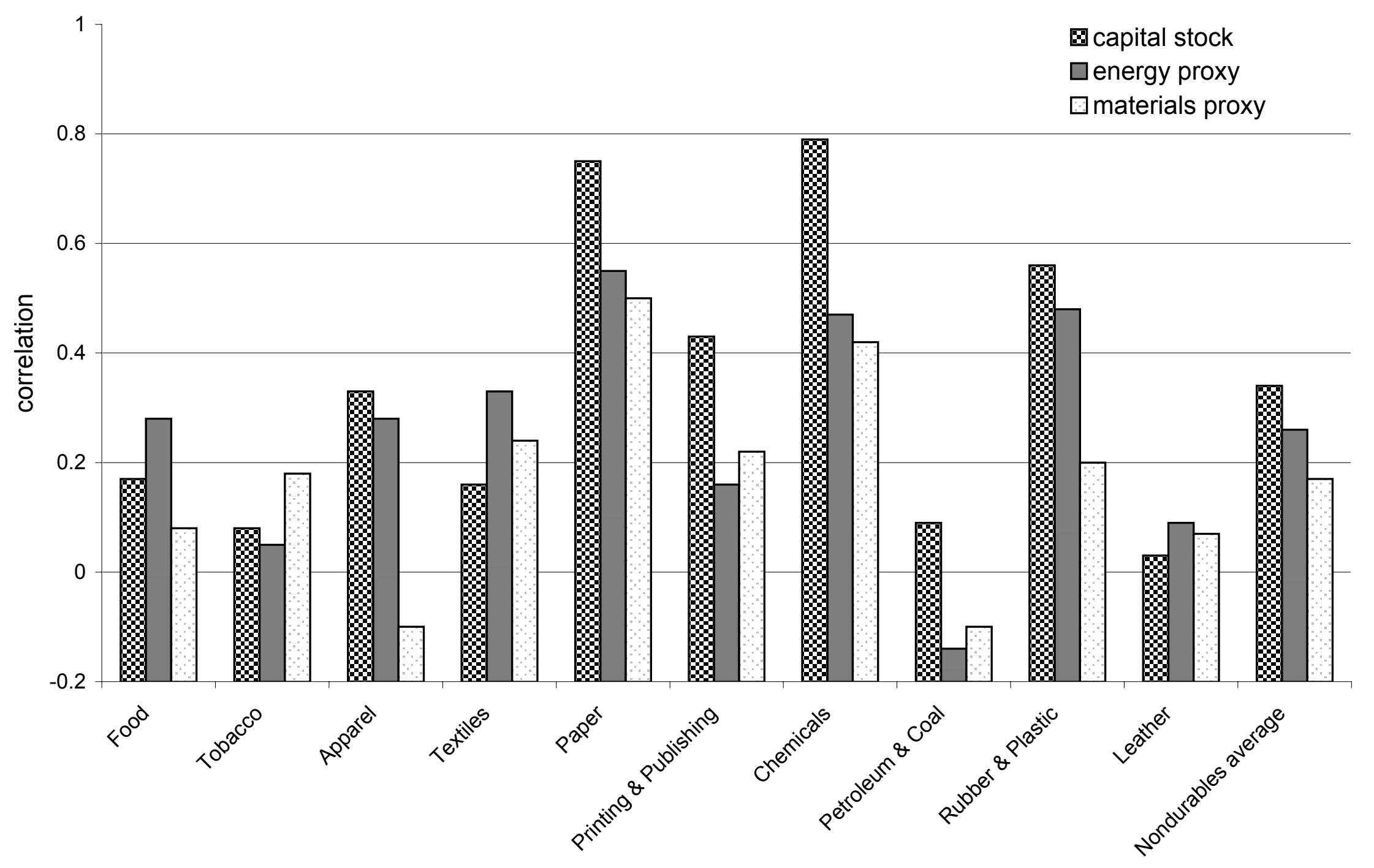

